\title{
DIÁLOGOS MODERNISMO Y VANGUARDIA: UNA NUEVA AUTORÍA FEMENINA. GRACIELA FIGUEROA NAVARRO (1899-1925)
}

\author{
Malva Marina Vásquez \\ Universidad Andrés Bello \\ Santiago de Chile, Chile \\ malmara@msn.com
}

RESUMEN / ABSTRACT

\begin{abstract}
El artículo aborda dos publicaciones en la prensa santiaguina de Graciela Figueroa Navarro, los que participan en candentes debates del medio literario de principios del siglo veinte. Por una parte, se muestran las aristas modernistas de su cuento "La Torre" (1921), el cual problematiza la visión aristocratizante de la estética arielista. Por otra parte, se analiza su poema póstumo "Imprecación del verbo gastado" (1925), el cual participa en el debate de Antiguos y Modernos, esto es, entre lo que se llamó "el arte nuevo", vanguardista y el arte modernista. Debate que se da como una reflexión crítica sobre la ideología de la novedad de la poesía cubista. El espesor simbólico del poema se articula en torno a referentes culturales paradigmáticos de la modernidad; la teoría del psicoanálisis, la de la radioactividad y el cubismo en las artes plásticas, en tanto promueven el cambio del sensorium; la discontinuidad y la fragmentación. El carácter de obra inorgánica (Burger) de la poesía cubista, su tendencia hacia la abstracción y el geometrismo tanto como la pérdida de realidad (Subirats) son cuestionadas como prácticas de una estética parasitaria.
\end{abstract}

Palabras clave: estética arielista, diálogo modernismo-vanguardia, Graciela Figueroa, obra inorgánica.

\section{DIALOGUES MODERNISM-AVANT-GARDE: A NEW FEMALE AUTHORSHIP.}

GRACIELA FIGUEROA NAVARRO (1899-1925)

The article discusses two press publications by Graciela Figueroa Navarro released in Santiago which are part of critical debates in the early twentieth century literary field. On the one hand, in her short fiction "La Torre" (1921) we can see modernist features that problematize the aristocratic-laden vision of the arielist aesthetics. On the other hand, her posthumous poem "Imprecación del verbo gastado" (1925) deals with the debate between 
Ancients and Moderns, or the interaction of "new art", avant-garde, and modernist art. This debate becomes a critical reflection on the ideology of the new in cubist poetry. The symbolic depth of the poem is articulated around paradigmatic cultural references of modernity, the theory of psychoanalysis, the theory of radioactivity, and cubism in plastic arts that promote a sensorium change through discontinuity and fragmentation. The notion of inorganic work (Burger) of cubist poetry, its tendency towards abstraction and geometrism, as well as the loss of reality (Subirats), are questioned as practices of a parasitic aesthetics.

KEYWORDS: Arielista aesthetic, dialogue modernism-avant-garde, Graciela Figueroa, inorganic work.

\section{INTRODUCCIÓN}

Este artículo se desglosa de un proyecto de rescate patrimonial de una nueva figura autoral en las letras chilenas de principios del siglo veinte: Graciela Figueroa Navarro (1899-1925) ${ }^{1}$. Proyecto que contempla la edición de un libro que recoge su producción escritural, la que, salvo escasas publicaciones en medios periodísticos de su época, permanece aún inédita ${ }^{2}$. En esta primera carta de presentación, damos a conocer dos escritos de Graciela, esperando convocar el interés de la crítica, en especial la que aporta miradas y puntos de vista que ayuden a diversificar los enfoques existentes sobre la escritura de mujeres del período. Tarea aún necesaria, si se considera que la recepción de las escritoras latinoamericanas de comienzos del siglo veinte, cuenta con escasas aproximaciones críticas e historiográficas que permitan abordarlas más allá de su carácter de figuras individuales (Luongo y Salomone). Ahora, si bien la trayectoria vital y artística de esta escritora fue breve -pues muere a los 26 años de edad de tuberculosis ganglionar-a nuestro parecer, su reflexión crítica sobre problemáticas y debates artístico-culturales candentes para su época, la tornan en un sujeto cultural relevante de estudio.

1 Graciela Figueroa Navarro es hija del educador Emiliano Figueroa Corro (18621916), Profesor de Francés y Alemán, quien fundó y dirigió la Escuela Normal de Curicó (1906). Su producción abarca casi un centenar de poemas inéditos, algunos cuentos y otros escritos. Además hay dos libretas de apuntes, las cuales requieren de una acuciosa labor de transcripción por su estado deteriorado. La autora del artículo es sobrina nieta de la escritora.

Proyecto de edición que está en etapa inicial de elaboración. 
La labor productiva de Graciela Figueroa Navarro tiene lugar en el contexto socio-político que la historiografía chilena ha denominado el Estado Parlamentario o República Oligárquica; período que va de 1891 a 1925. Contexto en el cual se va dando la paulatina integración de las mujeres en tanto actores sociales a la vida ciudadana. Nos encontramos en el marco de una modernidad emergente en Latinoamérica, la que se destaca por su efervescencia política, debido a "la incorporación creciente a la ciudadanía política de aquellos que no estaban incorporados: sectores medios, obreros, campesinos, mujeres, jóvenes; $y$, por otra parte, el propósito declarado de destruir la dominación oligárquica y el sistema político institucional, cultural que la legitimaban" (Kirkwood 54).

Las primeras incursiones en medios periodísticos de la autora se dan a partir de los años veinte. En este artículo, de sus tres publicaciones en la prensa santiaguina, focalizaremos la atención en dos de ellas, a modo de primer acercamiento a la singularidad de su poética "modernista" 3 . En rigor, su figura escritural se inscribiría dentro de un modernismo "crepuscular" (Giordano) o "de presencia epigonal" (Subercaseaux) ${ }^{4}$, en tanto estética de carácter residual en las producciones literarias del período. Ahora, estamos conscientes de que hablar del modernismo de Graciela Figueroa, es postularla como un "sujeto social inesperado" (de Lauretis, cit. en Valdés 47) para la ciudad letrada de su tiempo. Afiliación controversial, dado que una de las constantes tanto de la historiografía como de la recepción crítica ha sido inscribir la literatura de mujeres del período en la sensibilidad epocal del "Espiritualismo de vanguardia" (término acuñado por Inés de Echeverría). Estructura de sentimiento que se caracteriza por: "La idea de que la vida espiritual y la experiencia del alma es la más sublime y trascendente experiencia humana... una experiencia próxima al campo de la mística, de la religión y del arte" y cuyo "gran y casi único tema es la biografía interior" (Subercaseaux 91-92). Sensibilidad que, si bien comparte el imaginario modernista de Graciela Figueroa, también marca su diferencia, debido a la casi total ausencia en sus escritos de la escenificación

\footnotetext{
El modernismo hispanoamericano conjuga una serie de tendencias; el romanticismo tardío, el parnasianismo, el simbolismo, los tópicos y retórica rubendariana, entre otras.

$4 \quad$ Subercaseaux habla de "un tercer momento del Modernismo con dos etapas: primero una de relativa vigencia y difusión que va desde 1895 hasta la primera década del siglo, y otra de presencia epigonal y transformación, que va de 1910 hasta los años que siguen a la muerte de Darío (1916)" (52).
} 
del yo biográfico ${ }^{5}$. Pero, aquí solo dejamos esbozada esta cuestión, ya que su despliegue sobrepasaría los alcances acotados de este artículo.

A fin de mostrar las aristas modernistas del imaginario escritural de Graciela, abordaremos dos de sus escritos publicados en la prensa santiaguina de los años veinte. Daremos inicio a esta lectura, con su relato "La Torre", publicado en 1921, en el Diario La Nación (Concurso de cuentos). En este cuento veremos cómo se refractan los idearios de la estética arielista; tipo de sensibilidad artística que ya está siendo cuestionada por autores del modernismo tardío o epigonal. En segundo lugar, nos abocaremos a la lectura de su poema póstumo: "Imprecación del verbo gastado", publicado en la Revista Caballo de Bastos $\mathrm{N}^{0} 3^{6}$, el año 1925, a meses del deceso de la autora ${ }^{7}$. En este poema se actualiza la vieja querella entre antiguos y modernos en el precario campo literario de su tiempo. Esto es, el debate entre el arte tradicional; el modernista y lo que se denominó "el arte nuevo" o de vanguardia en el ámbito nacional. En la modernidad acelerada del período, como sabemos, la poética modernista ya tiene un carácter residual, debido a una serie de transformaciones de paradigmas culturales, científicos y artísticos, los cuales aportan nuevas técnicas al quehacer artístico. La relevancia de este poema radica, no solo en sus evidentes méritos literarios, sino en la sorprendente actualidad que hoy cobra, a casi un siglo de su publicación, su sólida reflexión crítica sobre el futuro devenir de las vanguardias artísticas.

\section{LA MODERNIDAD ARIELISTA: EL MOTIVO ASCENSIONAL DE LA TORRE}

La torre de marfil tentó mi anhelo: quise encerrarme dentro de mí mismo

\footnotetext{
En general, la crítica estudia la escritura de mujeres del período, vinculando su rol de actor emergente con la literatura de tono menor; de tipo confesional o intimista; inscribiéndolas en las narrativas autobiográficas o del yo.

6 Esta revista es la ex Andamios, (Colegio de Profesores de Chile), la que en su tercer y último número, cambia de nombre y, además de la dirección de Salvador Fuentes Vega, incorpora como codirector a Pablo Neruda.

En el índice de la revista figuran las siguientes palabras de homenaje de los directores de la Revista: "Chela Figueroa, esperanza en flor muerta hace tres meses".
} 
y tuve hambre de espacio y sed de cielo desde las sombras de mi propio abismo

Rubén Darío

De 1921 data la primera publicación de Graciela Figueroa; la de su cuento "La Torre", el que aparece bajo el seudónimo de Serenus, en el diario La Nación (Concurso de cuentos). Desde su título, esta ficción dialoga con la sensibilidad de la estética arielista; la idea de la vulnerable situación del artista en la emergente modernidad capitalista. Su posición de resistencia y marginación del mundo burgués, a fin de preservar el cultivo de su espiritualidad creadora. Estética arielista que impregna las creaciones epocales, y que reivindica "el ideal espiritual de la cultura latina, frente a Calibán, que encarna la materialidad, el cuerpo y el pragmatismo utilitario anglosajón" (Subercaseaux 74). El ensayo Ariel (1900) de Rodó, junto a Azul (1888) de Darío, se han considerado como textos paradigmáticos del modernismo, siendo el primero uno de los textos más leídos por las juventudes hispanoamericanas y el de mayor influencia en el campo socio-político. Así lo testifica también la producción escritural de Graciela Figueroa, ya que dedica uno de sus poemas a esta gran figura del modernismo, junto a la de otros, como Rubén Darío y Amado Nervo. Poemas en los cuales es recurrente el motivo modernista de divinización del poeta, como se ve en estos versos: "La veste de Cristo/Alba veste/rozó tu frente/ y así fuiste otro discípulo amado/¡Oh, poeta místico!”. (“A Amado Nervo”). Figuración del poeta que confirma la tesis de Octavio Paz, de que desde la época romántica se dan dos experiencias conformadoras de la literatura de Occidente: "cristianismo sin dios, paganismo cristiano" Rodó", el cual comienza aludiendo a la muerte de este escritor en la "patria del Dante", en su última estrofa se destaca la memoria de su fecundo legado para las generaciones venideras: ¡Qué importa la agonía de tu esperanza!/¡Qué importa el vencimiento de Ariel por Calibán!/si eres el río lento, dulce, sereno,/ que se brinda a la sed,/y en cuyas aguas el veneno/se disolvió en silencio,/si la última lección del Maestro,/ha sido callar"9.

La historia de Ariel, según Moraña, consiste en "la persistente evocación de la virginidad del espíritu, perdida en el contacto promiscuo con la realidad

\footnotetext{
"Doble transgresión: la muerte de dios convierte el ateísmo de los filósofos en una experiencia religiosa y en un mito; a su vez, esa experiencia niega aquello mismo que afirma: el mito está vacío, es un juego de reflejos en la conciencia solitaria del poeta" (Paz 23).

Poema inédito.
} 
... la que contamina el arte y pragmatiza la función intelectual, que abre las puertas y cierra las ventanas de los espacios interiores, que José Enrique Rodó percibía como un invernadero de orquídeas y nenúfares" (19). Esta visión aristocratizante del rol del artista, que conlleva la ideología del genio creador, es problematizada en el cuento de Graciela. Rasgo que develaría su filiación en la segunda promoción de escritores modernistas, a la que pertenecen, en el ámbito nacional, tanto Gabriela Mistral (1889-1957) como Pedro Prado (1886-1952). A partir de la segunda década del siglo XX se produciría lo que Grínor Rojo llama: "la segunda transformación de una modernidad que comprende las décadas de 1920 a $1950, \ldots$ período altamente significativo pues en él, se hace evidente la presencia de voces portadoras de visiones alternativas a los discursos oficiales" (Salomone, Cisterna, Luongo y Doll 9). En el marco del modernismo, entendido como sistema poético hegemónico, la producción literaria que se da en el segundo decenio de este siglo -como lo es la de Graciela Figueroa- correspondería a "la nueva promoción" (Osorio); la de un "modernismo crepuscular". En ésta última, se "realiza una modificación interna del proyecto modernista, en la que se jerarquizan de modo distinto -y aun inverso- las preferencias de sus antecesores consagrados" (Osorio XVII).

Su cuento "La Torre" aborda las repercusiones de la crisis moral, que llevan a una aspiración al enclaustramiento en variadas torres de marfil a escritores y artistas, participando esta autora en el debate de uno de los síntomas epocales del Chile del Centenario. Debate que tiene su modulación en el ámbito nacional, en el grupo artístico Los Diez, liderado por la figura del arquitecto y poeta chileno Pedro Prado, cuyo manifiesto artístico homónimo data de $1915^{10}$. Esta formación de artistas independientes que se distancian del nacionalismo y el naturalismo imperante en el medio literario" "reelaboran la estética del simbolismo y los aportes del modernismo, se interesan por la propuesta mundonovista abierta a las identidades latinoamericanas y por entender las tendencias emergentes del espíritu nuevo" (Lizama 161). El relato "La Torre" de Graciela Figueroa se articula como una alegoría de la tensionada situación del artista en la emergente modernidad capitalista

10 Grupo artístico que despliega su quehacer entre 1914 y 1918, y que vendría a inscribirse en el proceso de renovación modernista.

11 La primera década del siglo XX; período en que "asistimos a un nuevo y activo proceso de construcción intelectual y simbólica de la nación, que se expresa a través de distintas prácticas discursivas (los rituales de celebración del Centenario, la literatura de la crisis, la crónica periodística, las memorias o libros de viaje)" (Subercaseaux 12). 
de las urbes latinoamericanas. La topografía del despliegue semántico de oposiciones - cielo versus tierra- se da entre el motivo ascensional de la Torre, cuya elevación espiritual hacia el cielo contrasta con el lujo de la vida materialista de la urbe moderna, a la que se llama "ciudad subterránea". Sin embargo, estas polaridades avanzan hacia una síntesis en el diseño global del cuento. En este relato, un artista construye una "torre gris"; esto es, austera, en la cual se confina, tomando como paradigma de belleza e inspiración el espacio celeste, abismal, infinito. Su anhelo es escribir una obra sublime que conmueva con su belleza a "todas las almas" de la ciudad subterránea. Este predicamento es afín al motivo de la "belleza como alma del mundo" del manifiesto "Somera iniciación al Jelsé" (1915) del grupo Los Diez que lidera Pedro Prado ${ }^{12}$. Como señala Lizama: "Se trata de un manifiesto en que hay claros elementos modernistas como la espiritualidad, la preeminencia de lo estético, la relación entre la belleza sensible y la belleza ideal, pero también una crítica a la retórica modernista. "Venid palabras puras, livianas y encendidas como aves en vuelo luminoso" proclama un texto de Pedro Prado, de 1916" (155).

A los habitantes de la "ciudad subterránea" del cuento de Graciela se los ve "en un trabajo incesante entre sus luces y sus sedas, pensando sólo en el modo de adquirir más riquezas". El narrador nos describe la vida en esta ciudad con el sema de la sobreabundancia; en "maravillosa opulencia". Sin embargo, esta ciudad hedonista de la modernidad, se opone a la vida espiritual, la que solo germinaría, de acuerdo a los postulados arielistas, en contacto con la naturaleza primigenia. Frente a la contemplación de la belleza del azul del cielo infinito a que se aboca el artista del cuento, esta vida en la urbe moderna, solo convoca "contemplaciones de bellezas artificiales"; en tanto se consolida como lugar del mercantilismo y el consumo:

Sucedió esto en la ciudad subterránea, donde los hombres vivían en maravillosa opulencia; pero sin haber visto jamás el cielo. El poeta quiso escribir el verso que conmoviera a todas las almas, y para lograrlo

12 "Lejos de las ciudades populosas y de los alegres puertos; distante de la paz de las aldeas y de las mansiones solitarias de los misántropos, sin tierra que cultivar, sin siervos que proteger: sin ambiciones de dominio ni orgullo de ser enseñanza, ejemplo o guía; sobre un enorme y abrupto peñón que ha recibido durante cien siglos el ataque del mar y la esperanza de sus prodigiosas lejanías, se elevará tranquila, aislada y libre, la roja Torre de Los Diez" ((Prado, "La torre de Los Diez"). 
se encerró en la torre gris que construyera altiva, y coronada por la cúpula de Infinito. Allí permaneció largo tiempo soñando, mirando ese azul incomparable que los hombres de la ciudad subterránea habían desdeñado para entregarse a contemplaciones de belleza artificiales. -iQué desgraciados son!- decía el poeta al mirarles. (Figueroa 4; negritas mías).

La estrategia del cuento de Graciela Figueroa consiste en mostrar el escenario del conflicto ideológico de la subjetividad modernista, por medio de su desdoblamiento en dos hermanos artistas. El primer artista, inspirado en su sensibilidad arielista, crea su obra sublime ${ }^{13}$ y corre bajando de la torre, a mostrarles a los hombres de la ciudad subterránea "su precioso manuscrito". Pero éstos, al leerla, "prorrumpieron en carcajadas. -Pobre loco, tu obra es insensata. Y peor que eso, ella no dice nada..." (Figueroa). Y aquí irrumpe un hermano del primer artista, el que le pide habitar la torre, pues tiene la convicción de que él sí, logrará conmoverlos. Pero, a este hermano del primer artista le pesa el confinamiento voluntario y contempla desde el mirador de la torre los quehaceres cotidianos de los ciudadanos. Lo abate la nostalgia por la ciudad, por lo cual escribe un "salmo" al lujo y la libertad de la emergente modernidad capitalista. En este relato, estos dos hermanos vienen a alegorizar la estructura de sentimiento, escindida, del sujeto artista, letrado, en la incipiente modernidad capitalista, el cual para sobrevivir no puede eludir el desafío de buscar un posicionamiento en las nuevas reglas de juego sociales. Podríamos entender, entonces, la escritura del "salmo" a la ciudad subterránea, en homología a la emergencia de una nueva producción discursiva que surge del periodismo literario finisecular; la crónica urbana ${ }^{14}$.

13 "El poeta meditaba y escribía. Por la abertura azul de la torre bajaban ráfagas palpitantes y frescas. En las tardes, había arreboles que se detenían un momento para emprender viaje por el infinito, cuyo único punto servía al poeta para comprender el Todo. Y en las noches las estrellas le besaban la frente y con sus rayos finísimos bordaban el poema que debía conmover a los hombres de la ciudad subterránea" (Figueroa "La Torre").

14 Veáse Susana Rotker, La invención de la crónica. Esta autora propone como tesis principal la aparición de un nuevo género de escritura en América Latina: la crónica como forma narrativa que surge del periodismo literario finisecular. Se relaciona, por ende, al modernismo literario con el fenómeno de la modernización acelerada que se produce a fines de siglo en América Latina, en lo económico, lo político y lo social: "La condición de la crónica modernista implica una postura ambigua aunque en general crítica hacia el poder institucional y la burguesía, una forma de renarrativizar casi cotidianamente un orden real que se ha fragmentado" (Rotker 156). 
Este registro narrativo se atribuye a la corriente modernista, y principalmente se centra en la figura de José Martí, quien hacia la década de los ochenta, escribe artículos para La Nación de Buenos Aires y La Opinión Nacional de Caracas: Vamos al relato:

Su poema era un salmo a la vida subterránea que él viera bullir desde el alto mirador: era el jay! del desterrado que suspira por la tierra lejana... Y los hombres al escucharle, se sintieron emocionados, y le aplaudieron, y le coronaron, y le llevaron en triunfo al Capitolio, inundado de luces... Mas, el hermano del poeta, era también poeta, y sintió vergüenza. A la mañana, cuando aún duraba la fiesta hecha en su honor, y brillaban los candelabros que reemplazaban a la luz solar, se dirigió a la torre. Abrió la puerta, y encarándose con su hermano, que trabajaba sereno, le dijo: -Perdóname. Pero aún, soy digno de llamarme tu hermano, porque he desdeñado sus aplausos (Figueroa 4).

Es esta aclamación de la crónica por parte de las masas lectoras, la que describe a la urbe industrial, lo que permite la incorporación de este nuevo género al mercado de los bienes simbólicos. Se consagra con ello la nueva función social del escritor en el periodismo cultural. Lo que muestra la vinculación entre los procesos de modernización acelerada de las urbes ${ }^{15}$, a fines de siglo en América Latina, y los procesos de profesionalización del literato. Por su parte, la obra de arte puro, basada en el idealismo arielista, es incomprendida por el vulgo. Pese a ello, este artista felicita a su hermano, puesto que reconoce que su obra es fruto de la autenticidad. Y aquí, en esta actitud del primer artista, encontramos el motivo del valor otorgado a la autenticidad en el modernismo dariano, como podemos apreciar en el final del relato ${ }^{16}$ :

Y él, meditativo, contestó: -Tu poema vale la coronación hermano, porque es sincero. Si tú, sintiendo la nostalgia de la ciudad subterránea, hubieras fingido emocionarte ante el cielo, habrías hecho un poema

15 Respecto a la historia del desarrollo urbano de América Latina, veáse, Romero 1999. Ensayo en el cual aborda la historia del desarrollo urbano de América Latina, desde las "ciudades hidalgas, criollas, patricias, burguesas y masificadas". El movimiento modernista se corresponde a lo que José Luis Romero llama "la ciudad burguesa", la que a fines del siglo XIX pasa por un proceso de grandes transformaciones.

16 "La característica de Rubén Darío es la individualidad, la personalidad; ya él lo dijo: "mi poesía es mía en mí". La obra de Darío es grande porque es sincera y "ser sincero es ser potente" (Vicente García Fernández (Huidobro) en Musa Joven No 5, 1912: 5). 
torpe. Mas, así no ha sido. Y si vuelves a mi retiro, ansioso de conocer la verdadera Belleza, es que la presientes, y la llegarás a amar... Dijo, e hizo sitio al menor en la mesa de trabajo. Por la abertura de la torre, sobre el cielo azul pasó un ave cantando (Figueroa 4).

Se deja abierta así la posibilidad en el cuento de Graciela Figueroa, de que el artista modernista logre una conciliación entre su espiritualidad sublime y las demandas del mundo pragmático, burgués. Según Gutiérrez Girardot: "Tras el fin del arte, el arte no se refugió [...] en la 'Torre de Marfil', sino en un reino ambiguo en el que reinan la fantasía y la libertad, pero también la nostalgia del mundo y la sociedad que los expulsó" (68). El poeta experimenta lo que Hofmannsthal llamó "el gozar sufriendo", ya que "al ser relegado de la sociedad era un desamparado, sólo representaba al individuo absoluto y a la vez dependiente de la sociedad burguesa, del liberalismo" (68).

Osorio sitúa a la nueva promoción modernista en la etapa crepuscular de la estética modernista -obras entre 1910 y 1920- la que correspondería a la etapa final de la "modernización" en América Latina y que se caracteriza porque "representa un conflicto entre lo que la visión aristocrático-burguesa del mundo considera como bello y lo que los nuevos sectores (notablemente la pequeña burguesía) realmente conocen. Con ello ya se estaría planteando la crisis del modernismo canónico, la crítica hacia su alto grado de retorización, crítica a que coadyuva el fortalecimiento de la burguesía y la pérdida del poder económico de las oligarquías agrarias" (XVIII). Dentro de este medio ideológico es donde podríamos situar la reflexión que despliega Graciela Figueroa sobre la sensibilidad arielista en su cuento "La Torre", ya que se busca una conciliación entre la espiritualidad, de corte aristocratizante, y las exigencias del nuevo mercado de bienes simbólicos que rige a la modernidad burguesa ${ }^{17}$.

Cerrando este apartado de rasgos de modernismo epigonal en la producción escritural de la autora, nos referiremos a su segunda publicación en la prensa, la que da testimonio de que Graciela Figueroa conoció en persona a la primera escritora consagrada en el medio nacional; Gabriela Mistral ${ }^{18}$. En 1923, a dos

17 Lo cual, creemos, incidiría en una resignificación o ausencia en los escritos de esta nueva promoción de escritores del "modernismo crepuscular", del tópico de "la fijación objetual hedonista belle époque".

18 Gabriela Mistral, como sabemos, había ganado el concurso de los Juegos florales en 1916 con sus Sonetos de la Muerte. En 1922, había sido publicado y presentado en New York su poemario Desolación por Federico de Onís. 
años de su primera publicación en 1921 de su cuento La Torre, en la Revista Chile Magazine de la editorial Zig-Zag, aparecen 4 poemas en prosa, con una presentación de Gabriela Mistral. Entre las dos hubo una breve alianza de vocación por las letras, la que fuera interrumpida por la muerte prematura de Graciela, el año 1925:

Con estos cuatro poemas en prosa inicia la publicación de su escondida labor literaria de tres años una joven dotada de extraordinarias dotes: pensamiento hondo, claridad y firmeza de estilo y fina sensibilidad. Graciela Figueroa se ha formado con lecturas selectas. Sus maestros son Maestros. Ellos le han dado estas virtudes capitales que asoman desde sus comienzos: el orden mental, una naturalidad y una sencillez que no se tocan nunca con el descuido y una originalidad sin extravagancias (Mistral, cit. en Figueroa, "Cuatro poemas en prosa" 24).

Celebra la Mistral en su comentario crítico la formación lectora de la joven escritora, (a la sazón de 22 años), "en lecturas selectas". Esto es, su formación en el canon literario del período y se alude a que habría empezado a escribir en 1919. El otro comentario de la Mistral reconoce madurez autoral en Graciela, al decir que está dotada de "firmeza de estilo y fina sensibilidad"; ya que su pluma habría sorteado la prueba de lograr "una originalidad sin extravagancias". Además, la Mistral detecta un parentesco entre la escritura de Pedro Prado ${ }^{19}$ y la de Graciela: "Ha leído poco a Pedro Prado; aparece como influencia lo que viene a ser similitud espiritual" (24). Como vemos, desde la presencia del modernismo arielista en su cuento y la apreciación de la Mistral de un diálogo de la poesía de Graciela Figueroa con la de Pedro Prado, se abren fecundos horizontes de estudio de esta nueva autora.

19 La poesía de Pedro Prado (1886-1952) publicada hasta 1925 consta de: Flores de cardo 1908; La casa abandonada 1913, El llamado del mundo 1913; Los pájaros errantes 1915; Las copas 1919. Su manifiesto artístico Los Diez en 1915 y su novela célebre Alsino de 1920. Autor que ha sido inscrito en el modernismo crepuscular (Giordano, Osorio) o "de presencia epigonal y transformación, que va de 1910 hasta los años que siguen a la muerte de Darío (1916)" (Subercaseaux 138). 


\section{CAMPO CULTURAL NACIONAL: LA QUERELLA DE ANTIGUOS Y MODERNOS}

Contextualizar la participación de la autora en la querella entre antiguos y modernos ${ }^{20}$ que tiene lugar en su poema póstumo "Imprecación del verbo gastado" (1925), pasa por destacar el rol de las revistas en el campo cultural de principios del siglo veinte, en tanto órganos de difusión y reapropiación de las tendencias artísticas y/o los ismos europeos. Los comienzos de la difusión y recepción de las vanguardias europeas en Chile se han situado en los años que siguen a la celebración del Centenario: "particularmente en el año 1912 y siguientes, aparecen en revistas y periódicos chilenos los primeros textos que informan -o realizan una suerte de mediación comprensiva- respecto a la vanguardia internacional; es el momento en que diversas antologías literarias tematizan la polaridad "arte nuevo" versus "arte académico o tradicional" (Armando Donoso Los nuevos, 1912; Selva Lírica, 1917)"; (Subercaseaux 123). Pese a que en este tipo de controversias "... cada quien entiende por "nuevo" o por "espíritu nuevo" algo distinto, lo importante es el uso amplio y variado que se hace durante esos años de dicha polaridad" (Subercaseaux 123). En esta etapa de transición coexisten en el medio literario diferentes tendencias y movimientos; el realismo naturalista y criollista; lo residual; romanticismo, simbolismo, con lo emergente, cubismo, simultaneísmo ${ }^{21}$.

Proponemos leer el poema póstumo "Imprecación del verbo gastado" de Graciela Figueroa Navarro, a la luz de estas controversias en el medio literario, como una suerte de contramanifiesto de la poesía vanguardista, de aristas cubistas. Dicho rasgo unificador del tejido tanto semántico como pragmático histórico dado se tienen por actuales o modernos. Simplificando esta cuestión, tenemos que, alternativamente, se opta por valorar a los antiguos, postura normativista, a los que se considera genios que habrían legado una obra insuperable, o a los modernos, los que, saliéndose de los lugares comunes, interrogan al pasado y encuentran perspectivas innovadoras.

$21 \quad$ Respecto a las manifestaciones de la vanguardia nacional, entre 1912 y 1914 se produce el desplazamiento de la poesía de Huidobro "desde una estética canónicamente modernista y rubendariana a una estética de rasgos vanguardistas (desde Musa Joven en 1912, al manifiesto "Non serviam", de 1914), fenómeno que se repite en la poesía de Pablo de Rokha (poemas modernistas en el diario La mañana de Talca, en 1912, a Sátira, en 1918 y Gemidos en 1922)" (Subercaseaux 123). 
del poema, se advierte, por su carácter de palabra bivocal (Bajtin) ${ }^{22}$, la que se va modulando como una polémica explícita con sus destinatarios; los "poetas cubistas", a quienes se apela desde el primero hasta el último verso. De esta manera, este texto dialógico se puede entender como una "polémica explícita", ya que va dirigida con la intención de discutir, refutar la palabra ajena y el objeto del que ésta habla; a los poetas y a la poesía cubista. Este rasgo de contramanifiesto del poema se ve reforzado por la figura de la prosopopeya, ya que para generar la polémica, se construye a su hablante como "voz-postura," en tanto dispositivo enunciador y defensor de la poética modernista; es el "verbo gastado pero transmisor" (verso cuarto). A la vez, es un verbo que opera por continuum temporal, frente a la fragmentación que opera el montaje como técnica de yuxtaposición y/o fragmentación en el cubismo. Desde la perspectiva de la producción estética, es interesante cómo se ven confrontados en el poema de Graciela Figueroa Navarro, dos posiciones o posturas que implican modalidades artísticas diferentes. Por una parte, el arte tradicional o modernista; el arte orgánico - del cual es portavoz el verbo gastado- $y$, por otra, el arte vanguardista; el que aporta la categoría de obra de arte inorgánica, ya que "rompe con la apariencia de totalidad" (Burger 103) $)^{23}$ :

Poetas cubistas que renegáis de todo principio fundamental Yo, nuevo para mí mismo y a la vez tan antiguo como el mundo Raya continua hacia el vértice que todos adivinan y niegan

Os emplazo así con este verbo gastado pero transmisor

22 La palabra bivocal, para Bajtin (1987), posee doble orientación: hacia el objeto del discurso y hacia la palabra ajena. Ejemplos de palabra bivocal: la estilización, la ironía, la parodia, el relato oral y el diálogo. Este autor también distingue polémica implícita de polémica explícita. Si bien Bajtin analiza la palabra bivocal en la prosa, sus alcances también valen para la lírica: "Las palabras ajenas introducidas en nuestro discurso ineludiblemente se revisten de una nueva comprensión que es la nuestra y de. una nueva. valoración, es decir, se vuelven bivocales. La interrelación de estas dos voces puede ser muy diversa. Ya una repetición de una aseveración ajena en forma de pregunta lleva a la colisión de dos 'interpretaciones en un mismo discurso: nosotros no sólo preguntamos sino que también problematizamos la aseveración ajena" (272).

23 De acuerdo a Bürger, la vanguardia para reintegrar el arte a la praxis vital "violenta un sistema de representación que se basa en la reproducción de la realidad" (140). Por ello si la obra era creada como una totalidad orgánica que "se muestra como una obra de la naturaleza" (102), la obra de vanguardia, busca su separación de la institución arte, la que aloja al arte orgánico. 
para que me digáis qué nuevo ectoplama habéis fabricado con vuestros líquidos destilados en la trizadura de la subconsciencia.

(Figueroa 22)

A los poetas cubistas se les dirige una larga interpelación de carácter metapoética, que a través de figuras como las preguntas o conjeturas retóricas, buscaría descifrar el supuesto enigma en que consiste su pretensión de novedad artística. La ironía del hablante consiste en homologar la pretensión de novedad de los poetas cubistas con las creencias epocales sobre el espiritismo ${ }^{24}$ y los nuevos paradigmas en el campo del estudio del psicoanálisis. Estos nuevos alquimistas, los poetas cubistas fabricarían su "nuevo ectoplasma" (el fluido que expelerían ciertas personas en trance mediumínico), por medio de su conjugación con la irrupción de las pulsiones inconscientes ${ }^{25}$. Al dirigirse a los "poetas cubistas", el hablante nos informa que su crítica va dirigida a la llamada poesía visual, esto es, la que hace uso tanto de la diagramación gráfica para la formación de imágenes (en especial, los caligramas), como a la que se rige por el procedimiento de yuxtaposición de imágenes ${ }^{26}$. En cuanto a las primeras incursiones en la poesía visual en nuestro país, éstas se darían "a comienzos del siglo XX, de la mano de Vicente Huidobro, su más prominente y temprano exponente. En 1912, en la revista Musa Joven, el poeta publicó su primer caligrama, titulado "Triángulo armónico", considerado el primer poema visual publicado en Chile ${ }^{27}$.

$24 \quad$ "el desenvolvimiento del espiritismo en Chile (entre 1880 y 1920) fue ayudado principalmente, por una gran base espiritualista que mostraba una vigorosa salud en el lapso de tiempo estudiado. Como se ha recalcado, en torno a las inclinaciones espiritualistas convergieron cristianos, teósofos, espiritistas y masones y, en general, todo sujeto que proclamase el principio filosófico que concebía la realidad como algo irreductible únicamente a su fase material" (Muñoz 129).

25 En algunos de los trabajos prepsicoanalíticos tempranos de Freud, en idioma francés, el término "subconsciencia" fue utilizado como sinónimo de inconsciente. Freud lo abandonó a partir de 1900 .

26 De manera que la apelación a los "poetas cubistas", podría ser alusión directa a la etapa plenamente creacionista-cubista (1918-1925) de Vicente Huidobro, la que tiene su paradigma en Ecuatorial (1918).

27 "Los primeros poemas plenamente vanguardistas de Huidobro -traducidos al francés con ayuda del pintor Juan Gris-aparecieron en Nord-Sud (1917), revista que aspiraba a representar la tendencia cubista en literatura y que reconocía en Apollinaire al poeta que ... había "trazado rutas nuevas, abierto nuevos horizontes"” (Castro 155). 
El carácter de contramanifiesto del poema de Graciela se delata al asumir un similar gesto confrontacional ${ }^{28}$ al de las vanguardias históricas, por parte del verbo gastado. Vanguardias que se distinguen de otros movimientos anteriores, por la "explicitación programática de contenido formal innovador" (de Haro). Y es, precisamente, esta pretensión de "novedad" a la que se acusa de falaz en el poema, mediante una serie de conjeturas irónicas sobre el cambio de paradigmas en las artes. El espesor simbólico del poema se va articulando en torno al cruce de referentes culturales emblemáticos de la historia intelectual de principios del siglo veinte: el psicoanálisis, la teoría da la radioactividad ${ }^{29}$ y el cubismo en las artes. De ahí que esta crítica sea ambivalente, dado que es conciencia lúcida respecto a los descubrimientos, que promueven la transformación del sensorium y el estallido de lo que antes se consideraba más bien unitario; la conciencia y la materia ${ }^{30}$ :

Tal vez habéis ido a buscar los radioactivos

Allí donde el zapato deshormado de la que se llamó Ciencia,

Dio en parar; es decir, habéis fabricado sustancias diversas

Y penetrado en el fluído de las vísceras de Tutan kameses

y descubierto que la curva es la negación del esfuerzo, y que así el hombre no hizo otra cosa hasta ahora sino mirarse sin revés.

(Figueroa 22)

El arte cubista habría: "descubierto que la curva es la negación del esfuerzo", ya que al no regirse por la lógica de la continuidad y el fin, no requeriría de mayor trabajo del artista. Además, su actitud experimental dejaría al

28 "No se crea que la actual generación de poetas está alineada como continuación de la anterior. Precisamente su fuerza novedosa estriba en que es diametralmente opuesta". (Caballo de Bastos 8). A los poetas tradicionales se les denomina: "Los literatos cursis, los misoneístas, los poetas a caballo, los anquilosados, los animales de terreras" (Andamios 2, 2).

29 La radiactividad es una propiedad de ciertos elementos químicos cuyos núcleos atómicos son inestables: como el tiempo, para cada núcleo llega un momento en que alcanza su estabilidad al producirse un cambio interno, llamado desintegración radiactiva, que implica un desprendimiento de energía conocido de forma general como "radiación". Becquerel (1896) la descubre en una sal de uranio.

$30 \quad$ La conjetura "habéis penetrado en el fluído de las vísceras de Tutan kameses" atrae un imaginario de supersticiones de la década de los veinte, sobre las maldiciones de un faraón egipcio de la dinastía XVIII, del cual solo se tenía la referencia de un anillo con su nombre: Tut-Ankh-Amun, que traducido equivale a "Más que nunca está vivo Amon". Faraón que se habría vengado de la profanación de su tumba (1922), causando varias muertes. 
descubierto: "que así el hombre/ no hizo otra cosa hasta ahora que mirarse sin revés". El escenario de las vanguardias, como sabemos, es el de la densidad de la vida urbana, el de la velocidad de los nuevos medios de transportes, los que aceleran la percepción espacio-tiempo y, por consiguiente, tornan imposible una captación totalizadora de la experiencia. Producto de una modernización acelerada surge un nuevo sensorium, en un mundo en el cual, los habitantes urbanos transitan por un collage caleidoscópico de imágenes y sonidos ${ }^{31}$. Por ello, si la mirada clásica nos presenta un sujeto unitario y en las artes, una obra orgánica, ahora, según el verbo gastado, este sujeto se conoce en su reverso negativo o en los aspectos irracionales o reprimidos de su conciencia. En las artes, al código naturalista, regido por un sistema de representación orientado por una perspectiva central o de totalización, le sucede la estética de la fragmentación, la que hace proliferar las perspectivas y los tiempos, por medio del collage y el montaje.

\subsection{IDEOLOGÍA DE LA NOVEDAD Y VANGUARDIA}

Desde nuestro horizonte de clausura de las vanguardias históricas, sabemos que ese impulso de novedad artística de las vanguardias históricas era paradojal, pues había que negar el pasado y comenzar de cero a cada instante, lo que llevó a Paz a definir a las vanguardias como la "tradición de la ruptura". Huidobro en el manifiesto Non Serviam del Creacionismo ${ }^{32}$ cuestiona la mímesis realista: "No se trata de imitar la Naturaleza, sino de hacer como ella; no imitar sus exteriorizaciones sino su poder exteriorizador" ("La creación pura", cit. en Schwartz 111). El entendimiento del artista como creador absoluto se basa en la idea de que a la naturaleza hay que imitarla en sus leyes constructivas, en el mecanismo de la producción de nuevas formas, lo cual nos lleva al entendimiento aristotélico del arte como técnica (techné). Una obra de arte, dentro de esta concepción, "es una nueva realidad cósmica que el artista agrega a la naturaleza" (Huidobro), como lo es un cuadro, un

31 Veáse Berman (2004).

32 Como señala Schwartz: "El impacto de la poesía de Vicente Huidobro y la importancia de la teoría creacionista polarizaron, en cierta forma, los estudios sobre vanguardia en Chile. De modo que, si por un lado abundan los trabajos sobre el creacionismo, por el otro son pocas las investigaciones dedicadas a la generación vanguardista chilena" (97). 
gramófono, un aeroplano ${ }^{33}$. Para estudiosos de la vanguardia como Subirats, esta homologación entre arte y técnica del creacionismo de Huidobro forma parte de una tendencia general del arte abstracto moderno, el cual partiría de esta concepción de "la actividad o la creación artísticas como producción de un mundo propio o de una segunda naturaleza, como el poder derivado de una realidad artificial global. Es el principio de una creación ex nihilo que las corrientes de las vanguardias históricas asumieron en su conjunto,... desde el expresionismo hasta el construccionismo" (Subirats 27-28).

Pasando a la tercera estrofa del poema, la expresión "los ídolos triangulares truncos" hace referencia al culto a la abstracción figurativa o geometrismo, en tanto nuevo modo de representación adoptado por el collage cubista. En el cubismo, que fue introducido por Braque y Picasso (en el período del cubismo analítico), las figuras ya no son alegóricas ni simbólicas: "Se trata de máscaras desprovistas casi por completo de humanidad ...son problemas desnudos..." (Chipp 219); marcan un movimiento hacia la abstracción ${ }^{34}$ :

Los ídolos triangulares truncos, (aunque mucho me temo que no me comprendan)

Porque para vosotros nada está trunco ni existe el triángulo

Sino la visión reflejada de lo que no es,

Ni menos habláis de ídolos, porque éstos perecerían

En altar kilométrico proyectado hacia donde no va)

Sin embargo, yo que aún tengo boca no sexta esenciada

Os grito, (no temo herir vuestros tímpanos vueltos a imprimir)

que todo eso riel quebrado en innumerables pedazos

sale el antiguo riel que sustentó a la locomotora

(Figueroa 22)

La crítica a los poetas cubistas argumenta que el procedimiento técnico del simultaneísmo está animado por un afán deconstructivo de la unidad orgánica. Por ello "lo trunco" apunta precisamente al carácter de obra inorgánica del cubismo, en el cual las partes se "“emancipan" de un todo que está sobre ellas

33 Para este poeta, "[i]nventar consiste en que las cosas que se hallan paralelas en el espacio se encuentren en el tiempo o viceversa y, que al unirse muestren un hecho nuevo" (“Época de Creación”, cit. en Schwartz 114).

$34 \quad$ El poeta modernista Apollinaire, primer vocero de las poéticas vanguardistas contemporáneas y amigo de Picasso, señaló que este artista "estudia un objeto como un cirujano diseca un cadáver” (cit. en González, Calvo y Marchán). 
al que se integran como componentes necesarios. ... En un texto automático que yuxtapone imágenes, algunas imágenes podrían faltar sin que haya un cambio radical en el texto. ... No son fundamentales los sucesos en su singularidad, sino el principio constructivo basado en la yuxtaposición de sucesos" (Burger 113). Desde la perspectiva de la producción estética, vemos confrontados en el poema de Graciela Figueroa Navarro dos modos de arte; el tradicional o modernista, arte orgánico, y el vanguardista, obra inorgánica (Burger) ${ }^{35}$, el que "rompe con la apariencia de totalidad" (103). El término "Ídolo" es un término jerarquizador de valor aurático y la práctica cubista interviene, desfigura a los seres, bajo la actitud vital de un nihilismo generalizado. El "altar kilométrico hacia donde no va" (del verso quinto), sería la distancia insalvable que separa al hombre del ídolo o dios en los tiempos modernos; la pérdida del sentido de trascendencia. Arte vanguardista que ha llevado hasta su culminación el proceso de autonomización ${ }^{36}$ de la esfera estética de los otros ámbitos sociales. Debido a esta tendencia desacralizadora, reconoce el verbo gastado, que la abismal diferencia de posturas ideológico-estéticas solo conducen a la incomprensión de sus argumentos, por parte de sus contendores. En los versos tercero y cuarto de la segunda estrofa del poema, se acusa la ideología detrás de este procedimiento de la deconstrucción de la figuras. La realidad para los poetas cubistas sería tan solo una ilusión óptica, un anamorfismo, un simulacro: "Porque para vosotros nada está trunco ni existe el triángulo/ sino la visión reflejada de lo que no es". Esta pérdida de realidad que promueve el arte vanguardista ha sido percibida por relevantes teóricos de estas corrientes artísticas:

“igualmente promovida por Breton o Aragón es un lugar común de la revolución estética de las vanguardias artísticas modernas. ... La rebelión vanguardista contra el naturalismo y el mundo de

35 De acuerdo con Bürger, la vanguardia para reintegrar el arte a la praxis vital "violenta un sistema de representación que se basa en la reproducción de la realidad" (140). Por ello si la obra era creada como una totalidad orgánica que "se muestra como una obra de la naturaleza" (102), la obra de vanguardia busca su separación de la institución arte, la que aloja al arte orgánico.

36 "Solamente desde que el arte se ha separado por completo de toda referencia a la vida práctica, puede reconocerse la progresiva separación del arte respecto al contexto de la vida práctica, y la consiguiente diferenciación simultánea de un ámbito especial del saber (el ámbito de la estética) como principio del desarrollo del arte en la sociedad burguesa" (Burger 63). 
las apariencias, promovida desde el cubismo y el neoplasticismo expresan el mismo objetivo estético. La destrucción de lo real, la liquidación del papel del espectador y del arte como experiencia ejemplar son otros tantos aspectos de la subversión del "orden de la representación" (Subirats 25).

\subsection{ARte NUEVo: ARTE PARASitARio}

Frente a la tendencia cubista que hace abstracción de lo real, de la naturaleza sensible, el verbo gastado en el séptimo verso de la tercera estrofa declara su condición de cuerpo orgánico parlante: "yo que aún tengo boca no sexta esenciada". La ironía del hablante alude al hecho de que la nueva poética cubista conlleva un cambio del sensorium, la que se centra en la escucha: "vuestros tímpanos vueltos a imprimir", señalando la incidencia de lo tecnológico en esta mutación. Finalmente, se entrega la argumentación de fondo. Esta consiste en negarle estatus de novedad al arte cubista, ya que en el fondo, estas experimentaciones serían tan solo parasitarias del movimiento artístico que les precede, el modernismo: "que todo eso riel quebrado en innumerables pedazos/sale el antiguo riel que sustentó a la locomotora". Aquí entendemos que, para el verbo gastado, la intención de emancipación de las partes en la obra vanguardista tampoco avanza lo suficiente como para liberarse completamente del todo de la obra. El ejemplo del poema devela la importancia de la locomotora ${ }^{37}$ en tanto ícono de la omnipresencia de la velocidad en la modernidad y del cambio del sensorium, debido a la invención de nuevos transportes. Y llegamos a la cuarta y última estrofa de este poema:

Y os digo más claramente, para mí al menos

Y para ustedes, ya que son y para hacerse nuevos

Debieron haberse formado antes de ser

Que en vuestro afán por lo ultra plano anímico

No habéis más que colgaros a los riñones de los dioses antiguos

Para auscultarles el corazón...

(Figueroa 22)

37 "En Ecuatorial... la ciudad se presentaba en proceso de desmaterialización, a través de imágenes que personificaban objetos bajo una pulsión violenta y destructiva: "silba la locomotora en celo", "Cada estrella/ es un obús que estalla", "Los ocasos heridos se desangran". ..."El tren es un trozo de la ciudad que se aleja". Incluso más, es posible que la propia naturaleza adquiera las características de esta máquina a vapor: "La cordillera andina Veloz como un convoy Atraviesa la América Latina” (Alberdi 502). 
La crítica del verbo gastado termina dando argumentos contundentes para considerar cerrado el debate modernismo y vanguardia. La revolución de la representación que encarna el cubismo, el que transformó las artes, rompiendo con el sistema de representación del realismo y del naturalismo, sería tan solo de carácter parasitario. Lo cual se constataría en el concepto mismo con el cual surge la misma modernidad; el del cambio o la ideología de lo nuevo, el cual presupone una forma anterior, la naturalista. En el ámbito de las letras chilenas, relevamos en este artículo la participación de Graciela Figueroa Navarro en el debate intelectual y artístico sobre la estética arielista y su modulación en el ámbito nacional. También analizamos su poema póstumo, el cual entra en el debate de antiguos y modernos. Poema que, leído hoy, cobra una inusitada actualidad. Desde nuestro horizonte histórico de agotamiento del arte moderno, el poema "Imprecación del verbo gastado" nos sorprende por su carácter lúdico, incisivo y en gran medida profético sobre el devenir del arte moderno y su culminación en las vanguardias. Esta suerte de contramanifiesto del verbo gastado argumenta en sus versos finales que los poetas cubistas "en vuestro afán por lo ultra plano anímico/no habéis más que colgaros de los riñones de los dioses antiguos para auscultarles el corazón". Lo cual aludiría a los resultados de las investigaciones antropológicas y a la valoración de las culturas premodernas, a principios de siglo veinte. Sobre todo, a la importancia del primitivismo del arte africano en Picasso o de Oceanía en Breton, lo que devela las paradojas de la pretensión de novedad artística de las vanguardias, ya que, "[1]o viejo de milenios también puede acceder a la modernidad: basta con que se presente como una negación de la tradición y que nos proponga otra" (Paz 14)

Este poema, publicado a meses del deceso de la joven escritora, a sus 26 años de edad, en la Revista Caballo de Bastos (ExAndamios), el año 1925, nos aporta una irónica reflexión crítica que anticipa el futuro de las vanguardias artísticas. Y es que, en efecto, estos movimientos artísticos con su exacerbación de "la ideología de lo nuevo", esto es, con su instauración de lo que Paz denomina la "tradición de la ruptura" terminan por provocar el ocaso de la modernidad estética. Al convocar el poema en su verso final

38 Incluso, la poética del creacionismo de Huidobro, vista desde esta arista, también se acercaría a una "auscultación" del corazón de los dioses antiguos, puesto que la evolución de la historia del arte consiste en "ir del hombre espejo al hombre dios". Idea del artista como creador absoluto que, según cuenta Huidobro, se la sugirió un viejo poeta indígena, aymara que le dijo: "El poeta es un dios; no cantéis a la lluvia, poeta, haz llover" (Cit. en Osorio). 
al órgano vital, por excelencia, el "corazón," nos advierte que el arte solo subsistirá si no rompe su arraigo y vínculo con la naturaleza sensible. Ese mismo año 1925 de la muerte de Graciela Figueroa Navarro, aparece el célebre ensayo de Ortega y Gasset, La deshumanización del arte, en el cual el autor reflexiona sobre la enajenación de la experiencia de la realidad en el nuevo arte: "El placer estético para el artista nuevo emana de ese triunfo sobre lo humano; por eso es preciso concretar la victoria y presentar en cada caso la víctima estrangulada" (Cit. en Rojas 210). Para Rojas, esta deshumanización de las condiciones mismas de la experiencia, que se encuentra en la base de las vanguardias artísticas "negativas", "hacen de la experiencia en el arte un proceso, una mediación formal que suspende la pre-datitud de la realidad, por cuanto ésta, en el siglo XX ..., ha devenido una suerte de incógnita a despejar" (211) y el arte mismo, en su autonomía, un tipo de realidad "que se encamina hacia el agotamiento de su potencial mimético" (213).

\section{BIBLIOGRAFÍA}

Alberdi, Begoña. "La revista Andamios: apertura, voces divergentes y pluralidad máxima". Aisthesis $\mathrm{N}^{0} 50$ (2011): 253-274.

Bajtin, M. "La palabra en Dostoievsky”. Problemas de la poética de Dostoievsky. México: Fondo de Cultura Económica, 1986.

Berman, Marshall. Todo lo sólido se desvanece en el aire. La experiencia de la modernidad. Siglo Veintiuno editores, 2004.

Burger, Peter. Teoría de la vanguardia. Trad. Jorge García. Barcelona: Ediciones Península, 2000.

Castro, Belén. "Los horizontes abiertos del Cubismo: Vicente Huidobro y Pablo Picasso". Anales de Literatura Chilena, Año 9, Número 9 (2008): 149-167.

Chipp, Herschel. Teorías del arte contemporáneo. Madrid: Ediciones Akal, 1995.

De Costa, R. En pos de Huidobro. Santiago: Ed. Universitaria, 1980.

Huidobro. Los oficios de un poeta. México: Fondo de Cultura Económica, 1984.

Doll, Darcie. "Escritoras chilena de la primera mitad del siglo veinte: trayectoria en el campo cultural literario como criterios de periodización”. Taller de Letras No 54 (2014): 23-38.

Figueroa Navarro, Graciela. Poema “Imprecación al verbo gastado”. Caballo de Bastos №3, ExAndamios, 1925.

"Cuatro poemas en prosa”. Presentación de Gabriela Mistral. Chile Magazine $\mathrm{N}^{\circ} 13,21$ de febrero, 1923.

"La Torre". Concurso de Cuentos La Nación, 5 de octubre, 1921.

García Fernández, Vicente (Huidobro). Revista Musa Joven No 5 (1912): 3-5. 
Giordano, Jaime. La edad del ensueño. Sobre la imaginación poética de Rubén Darío. Santiago de Chile: Editorial Universitaria, 1976.

González, A, F. Calvo y S. Marchán. Escritos de arte de vanguardia. Madrid: Ediciones Akal, 2009.

Gutiérrez Girardot, Rafael. Modernismo: supuestos históricos y culturales. México: Fondo de Cultura Económica, 1988.

Kirkwood, Julieta. Feminarios. Santiago de Chile: Ediciones Documentas, 1987.

Lizama, Patricio. "Estudio". Notas de Arte (Jean Emar en La Nación, 1923-1927). Santiago: Dibam/RIL Editores, 2003. 9-43. Medio impreso.

"Manifiestos y utopías, viajes y videncia: una lectura mística de Pedro Prado". Revista Chilena de Literatura 82 (Noviembre 2012): 159-177.

Luongo, G. y A. Salomone. "Crítica literaria y discurso social: feminidad y escritura de mujeres." Iconos. Revista de Ciencias Sociales 28 (Quito 2007): 59-70.

Moraña, Mabel. "Revistas culturales y mediación letrada en América Latina". Crítica Impura. Madrid: Iberoamericana-Vervuert, 2004. 239-246. Medio impreso. [Links]

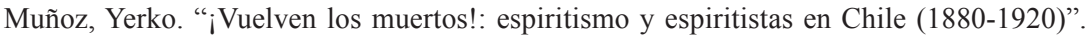
Informe Seminario de Grado. Licenciado en Historia. Santiago, 2012.

Osorio, Nelson. Manifiestos proclamas y polémicas de la vanguardia literaria hispanoamericana. Caracas: Biblioteca Ayacucho, 1988.

Paz, Octavio. Los hijos del limo. Del romanticismo a la vanguardia. Barcelona: Seix Barral, 1998.

Prado, Pedro. "La torre de Las Diez”. Los Diez 1 (1916): 71-73.

"Somera iniciación al Jelsé”. Los Diez 1 (1916): 5-12.

Rojas, Sergio. El arte agotado. Magnitudes y Representaciones de lo Contemporáneo. Santiago: Sangría Editora. 2002.

Romero, José Luis. Latinoamérica: las ciudades y las ideas. Medellín: Editorial Universidad de Antioquía, 1999.

Rotker, Susana. La invención de la crónica. Buenos Aires: Ediciones Letra Buena, 1992.

Schwartz, Jorge. Las vanguardias latinoamericanas. Textos Programáticos y Críticos. México: Fondo de Cultura Económica, 2002.

Subercaseaux, Bernardo. Genealogía de la vanguardia en Chile (La década del centenario. III). Santiago: Lom, 1998.

Subirats, Eduardo. Una última visión del paraíso. México: Fondo de Cultura Económica. 2004.

Salomone, Alicia, Natalia Cisterna, Gilda Luongo, Darcie Doll y Graciela Queirolo. Modernidad en otro tono. Escritura de mujeres latinoamericanas (1920-1950). Santiago: Cuarto Propio, 2004.

Todorov, Zvetan. "El arte como artificio". Teoría de la literatura de los Formalistas rusos. México: Siglo XXI, 1965.

Valdés, Adriana. Composición de lugar. Escritos sobre cultura. Santiago de Chile: Editorial Universitaria, S.A, 1996. 